\title{
McAlevey, J. (2016) No Shortcuts: Organizing for Power in the New Gilded Age; Oxford University Press.
}

\section{Review by Gary Jones}

For more than a decade organizer, author, and scholar Jane McAlevey has argued, in person and now in print, that while past organizing errors have undermined the labor movement, future organizers can learn from those errors, avoid repeating them, and rebuild the labor movement. As such, No Shortcuts: Organizing for Power in the New Gilded Age is quickly becoming an important and influential text among many committed to rebuilding the labor movement and promoting progressive social change in the $21^{\text {st }}$ century.

Since the publication of her first book, Raising Expectations (and Raising Hell): My Decade Fighting for the Labor Movement (Verso, 2012), McAlevey has earned a PhD in sociology from the City University of New York in 2015, served as a Post-Doctoral Fellow in the Labor and Worklife Program at Harvard Law School, and published A Collective Bargain: Unions, Organizing, and the Fight for Democracy (HarperCollins Publishers, 2020) in addition to No Shortcuts. Currently a senior fellow at UC Berkeley's Labor Center, part of the Institute for Research on Labor and Employment, McAlevey is also a regular contributor to The Nation and Jacobin.

In brief, Chapter 1 of No Shortcuts begins with the author - correctly - stressing the significance of the labor movement's post-war shift away from the organizing of the early CIO and towards the mobilizing and advocacy of the reunited AFL-CIO and New Labor. This shift, McAlevey adds, coincided with a historic decline of the labor movement, from which it has yet to recover. In Chapter 2 McAlevey proposes a return to an updated CIO-style 'whole-worker organizing' and describes what such organizing means on-the-ground. In Chapters 3-5 McAlevey provides thoroughly researched and well-documented 'paradigmatic' case studies of campaigns by 1199NE and nursing home workers in Connecticut, the UFCW and slaughterhouse workers at Smithfield Foods, Tar Hill, North Carolina, and the Chicago Teachers Union and public educators and staff, Chicago, Illinois, respectively, all of which have recently won using a 'whole worker organizing' approach. Chapter 6, in contrast, provides a case study of the mobilizing approach of worker center Make the Road New York, Brooklyn, NY. Chapter 7 concludes with McAlevey's observation that when it comes to 'actual power,' as opposed to 'pretend power,' there are 'no shortcuts.'

Of course, McAlevey is aware that the labor movement faces external as well as internal obstacles. Nevertheless, given that some of the above-mentioned external obstacles have been weakened, if not yet removed, due to the impact of the Covid-19 pandemic, the election of 2020, and the introduction of the PRO-Act, the publication of No Shortcuts has come at a propitious moment for the U.S. labor movement, as many more workers are now ready to join unions, organize, and strike. Readers are therefore most likely to be drawn to McAlevey's 'paradigmatic' case study of 1199NE's 'whole-worker' approach, based as it is on class struggle, organizing, strike-readiness, and collective bargaining, that has yielded the best contracts for private nursing home workers in the industry. Perhaps such militancy is hardly surprising, as 1199NE's roots lie in 1199, the CIO-era union, left-led, that organized Black, 
Puerto Rican, and female hospital workers during the 1960s-1970s, and aligned itself with major social movements of the day. To be fair, the author's other case studies, of the unjustly obscure UFCW union and slaughterhouse workers at Smithfield Foods, Tar Heel, North Carolina and the justly famous CTU and public-school educators and staff, also demonstrate the utility of 'whole-worker organizing.' For McAlevey such an approach is necessary for the labor movement to have the 'power to win' the NLRB certification elections, card checks, strike authorization votes, supermajority strikes, and good contracts that bring 'life-changing gains' to workers, and in the process contribute to rebuilding the labor movement and promoting progressive social change.

Most recently, the author has returned to her own roots as an organizer. Since the publication of No Shortcuts, McAlevey, working with the Rosa Luxemburg Stiftung, a socialist foundation based in Germany, has led a series of online 'Strike Schools' to train and develop thousands of organizers from the U.S. and abroad. As sponsored by the RLS and led by McAlevey, 'Strike School' is free and consists of one three-hour session offered every Tuesday for six weeks. Press reports indicate that course materials include No Shortcuts and a Strike Manual and the curriculum covers 'whole worker organizing' techniques such as workplace leader identification; semantics and six-step structured organizing conversations; workplace and community charting; structure tests; and strike mobilization. In order to best assist current campaigns and build collective organization, McAlevey and the RLS have now restricted registration for strike school to groups and organizations rather than permitting individuals to register as they had before. (Registration for future 'Strike Schools,' can be found at McAlevey's website, janemcalevey.com).

In sum, in No Shortcuts McAlevey provides a convincing argument for her often-expressed view that while past organizing errors have undermined the labor movement, organizers can learn from their errors, avoid repeating them, and rebuild the labor movement. As such, No Shortcuts has become an important and influential text among many committed to the long, hard, critical work of organizing that remains indispensable to rebuilding the labor movement and promoting progressive social change. For McAlevey, her readers, Strike School alumni, and many others, there is only one thing left to say and do, organize!

\section{Reviewer Bio}

Gary Jones is a U.S. historian who has taught many of the major eras and themes of American history at Muhlenberg College, Allentown, Pa., and American International College, Springfield, MA. His research focuses on the labor and working-class history of Gilded Age and Progressive Era Pennsylvania. 